\title{
Diverse origins of microbial L-asparaginases and their current miscellaneous applications
}

\author{
Nada A. Abdelrazek ${ }^{a}$, Walid F. Elkhatib ${ }^{\text {b,c* }}$, Marwa M. Raafat ${ }^{a}$, Mohammad M. Aboulwafa \\ ${ }^{a}$ Department of Microbiology and Immunology, Faculty of Pharmaceutical Sciences and Pharmaceutical Industries, \\ Future University, Cairo, Egypt \\ ${ }^{b}$ Microbiology and Immunology Department, School of Pharmacy \& Pharmaceutical Industries, Badr University in \\ Cairo (BUC), Entertainment Area, Badr City, Cairo, Egypt \\ ${ }^{c}$ Microbiology and Immunology Department, Faculty of Pharmacy, Ain Shams University, Abbassia, Cairol1566, \\ Egypt
}

\begin{abstract}
L-asparaginase, also known as amidohydrolase, catalyzes the breakdown of asparagine into aspartic acid and ammonia. Due to its ability to inhibit the biosynthesis of protein lymphoblasts, it is used to treat acute lymphoblastic leukemia (ALL). It also has other applications in the food industry by preventing the formation of acrylamide. Different organisms including bacteria, fungi, actinomycetes, and plants produce L-asparaginase. This review highlights different applications of L-asparaginase in the industrial fields, the major sources of L-asparaginase, its immunological reactions and production techniques through the solid state (SSF) and submerged (SmF) fermentation as well as optimization of the production process.
\end{abstract}

Keywords: L-asparaginase; Characterization; Optimization; Acute lymphoblastic leukemia.

*Correspondence | Walid F. Elkhatib, Microbiology and Immunology Department, Faculty of Pharmacy, Ain Shams University, Abbassia, Cairo11566, Egypt. Email: walid-elkhatib@pharma.asu.edu.eg; walid.elkhatib@buc.edu.eg; https://orcid.org/0000-0001-5815-3200

Citation | Abdelrazek NA, Elkhatib WF, Raafat M M, Aboulwafa M M. 2019. Diverse origins of microbial L-asparaginases and their current miscellaneous applications. Arch Pharm Sci ASU 3(1): 21-36

DOI: $10.21608 /$ aps.2019.20220

Online ISSN: 2356-8380

Print ISSN: 2356-8399

Copyright: () 2019 Abdelrazek et al., this is an open-access article licensed under a Creative Commons Attribution 4.0 International License (CC BY 4.0), which permits unrestricted use, distribution, and reproduction in any medium, provided the original author(s) and source are credited Published by: Ain Shams University, Faculty of Pharmacy

\section{INTRODUCTION}

Enzymes play an important role in metabolic and biochemical reactions and microorganisms are the primary source [1] because they can be cultured in large quantities in a short span of time $[2,3]$. Proteins that are used as therapeutics have made a great effect in the healthcare area, as they are specific in the disease, highly effective drug, and safe. They have a broad difference of specific utilities as thrombolytics and oncolytic. One of this therapeutic protein is L-asparaginase which has been found to be effective for the treatment of acute lymphoblastic leukemia[4].

Malignant cells differ from the normal cells, that it can barely synthesize L-asparagine, due to the absence of L-asparagine synthetase, so draining the circulating pools of L-asparagine by L-asparaginase leads to tumor cells destruction, so they could not be able to complete the synthesis of the protein through inhibition of RNA and DNA synthesis with subsequent blastic cell apoptosis [5]. 
L-asparaginase has been combined to the multidrug chemotherapy in adults and children with Hodgkin's disease, lymphosarcoma, reticulosarcoma, acute lymphoblastic leukemia, acute myelocytic leukemia, and melanosarcoma and it provides significant improvement of the outcomes of the therapy to achieve complete remission in about $90 \%$ of patients [6].

Recent advances in food technology have explained that pretreatment of potato slices and bread dough with asparaginase before frying or baking prevents acrylamide formation (carcinogenic toxicant) used in a large number of food products that are prepared at temperatures above $100{ }^{\circ} \mathrm{C}$ [7].

\section{L-asparaginase, application, types, and sources}

L-asparaginase (asparagine amidohydrolase) is a tetramer protein, otherwise called aminohydrolase relates to the amidase group of the enzyme and can break down L-asparagine into aspartic acid and ammonia [8].

\subsection{Its application as a tumor inhibitor}

It has a chemotherapeutic characteristic against the tumor cells. It is a powerful curable agent for treatment of lymphosarcoma and acute lymphoblastic leukemia [9]. L-asparaginase is the first curative protein with antineoplastic properties that have been examined comprehensively by many researchers far and wide [8].

L-asparaginase is recorded in the nineteenth WHO List of Essential Medicines and WHO Model List of Essential Medicines for Children as a cytotoxic and adjunctive treatment for intense lymphoblastic leukemia. Among different treatments, for example, corticosteroid and vincristine, L-asparaginase is utilized as a remission induction chemotherapy standard treatment alternative for recently diagnosed acute lymphoblastic leukemia [10]. It is used also as a central nervous system-directed systemic chemotherapy prophylaxis with dexamethasone and methotrexate for the high and standard-risk acute lymphoblastic leukemia. However, it could not penetrate into the cerebrospinal fluid (CSF), but it could deplete the CSF asparagine.

L-asparaginase discovery and development as an anti-cancer drug started in 1953 when Kidd initially noticed that the lymphomas in mice and rats disappeared after the treatment with the serum of guinea pig. Subsequent investigations demonstrated that it was the enzyme Lasparaginase which was in charge of the tumor relapse [11]. Other authors demonstrated that malignantly changed hematopoietic cells are now and again unfit to form adequate asparagine for their own metabolism when there is no dietary supply of this amino acid. The consumption of the systemic pool of asparagine performed by Lasparaginase will then prompt death to the cells [12]. Altenbern in 1954 and Broome in 1965 reported the antitumor activity of L-asparaginase in bacteria and yeast, respectively [8]. Lasparaginase is present in guinea pigs serum and rodents but is truant in humans. Two isozymes of L-asparaginase, in particular, type I and type II, have been recognized by Ohnuma [13]. Both type I and type II asparaginases are portrayed by enzymatic activity for both L-glutamine and Lasparagine. In any case, type II asparaginase shows higher particular action towards Lasparagine. Type II asparaginase definitely demonstrates antitumor activity and is used as chemotherapeutics in ALL [8].

The molecular basis for L-asparaginase therapeutic use stays badly clarified. In mammalian cells, the amino acid response (AAR) pathway is intended to recognize and react to amino acid inadequacy, which upon ending the supply of L-asparagine, enhances the expression 
of asparagine synthetase mRNA in the resistant cells. In any case, the expression of asparagine synthetase in susceptible tumor cells is not upregulated may be due to a decrease of the translation initiation, that is realized by the phosphorylation of eukaryotic initiation factors (e.g. eIF-2 a and eIF4e) by a starvation-activated ribosome-associated kinase [14]. L-asparaginase treatment causes specific starvation of the susceptible tumor cells. This L-asparagine starvation prompts the prevention of development of rRNA transcription, trailed by the discouragement of the synthesis of asparaginyl tRNA which limits peptide synthesis. Lasparagine consumption is additionally caused by nucleotide biosynthesis slowing and elongation of the S-phase of the cell cycle. L-asparaginase therapy captures the cell cycle of the tumor cell at the G1 phase before DNA degradation. Ammonium ions (one of the by-products of Lasparaginase activity) change the $\mathrm{pH}$ by disruption into the cytosol, which stimulates the pathway of the signal transduction associated with substrate phosphorylation and apoptosis [15]. Microbial L-asparaginases are marketed for medical applications under the brand names Kidrolase $^{\circledR}$, Elspar $^{\circledR}$ [7].

Mechanism of action: Both normal and leukemic cells need the amino acid L-asparagine, for their metabolic requirements. Normal cells can form L-asparagine for their development by using transaminase enzyme that changes oxaloacetate into an intermediate aspartate, which after that transfers an amino group from glutamate to oxaloacetate producing $\alpha$-ketoglutarate and aspartate. At last, in healthy cells, aspartate is changed into asparagine-by-asparagine synthetase. Neoplastic cells do not have the ability to form the asparagine due to the lack of L-asparaginase synthetase, hence are dependent on the external supply of asparagine for their existence and proliferation. Accordingly, providing the tumor cells with L-asparaginase can deplete all circulating asparagine, which leads to cancer cells starvation and death (Fig. 1 and 2). Clinical information published over the most recent two decades states asparaginase is an essential constituent of treatment protocols for ALL. L-asparaginase is predominant among microorganisms and eukaryotes [16].

\subsection{L-asparaginase application in food industry}

The University of Stockholm and the Swedish Food Authority affirmed the presence of the cancer-causing agent acrylamide in assortments of heated foods ten years ago. A while after the declaration, researchers demonstrated that acrylamide is synthesized from asparagine and reducing sugars during the Maillard reaction (Fig. 3) [17]. Since 2002, the food industry has teamed up with scientists worldwide, in order to lessen the amount of acrylamide in cooked foods. Techniques of mitigation can be isolated into three distinct types. Firstly, using starting materials with a low amount of acrylamide precursors can be utilized to decrease the acrylamide in the last product. Secondly, process parameters may be adjusted, in order to lessen the formation of acrylamide. Thirdly, post-process treatment could be utilized to decrease acrylamide [18]. However, the third approach is not used widely; an example is the utilization of supercritical $\mathrm{CO}_{2}$ extraction to decrease the levels of acrylamide in coffee. Almost $80 \%$ of the acrylamide was expelled utilizing this strategy [19]. Adding other chemicals before or after heating could reduce the amount of the produced acrylamide in a heated product, numerous added substances were utilized, as glycine who can contend with the asparagine to reduce the final acrylamide production, antioxidants and divalent cations as calcium hydroxide all have their side effects (affecting flavor of food) which prevent to be used commercially [20]. 


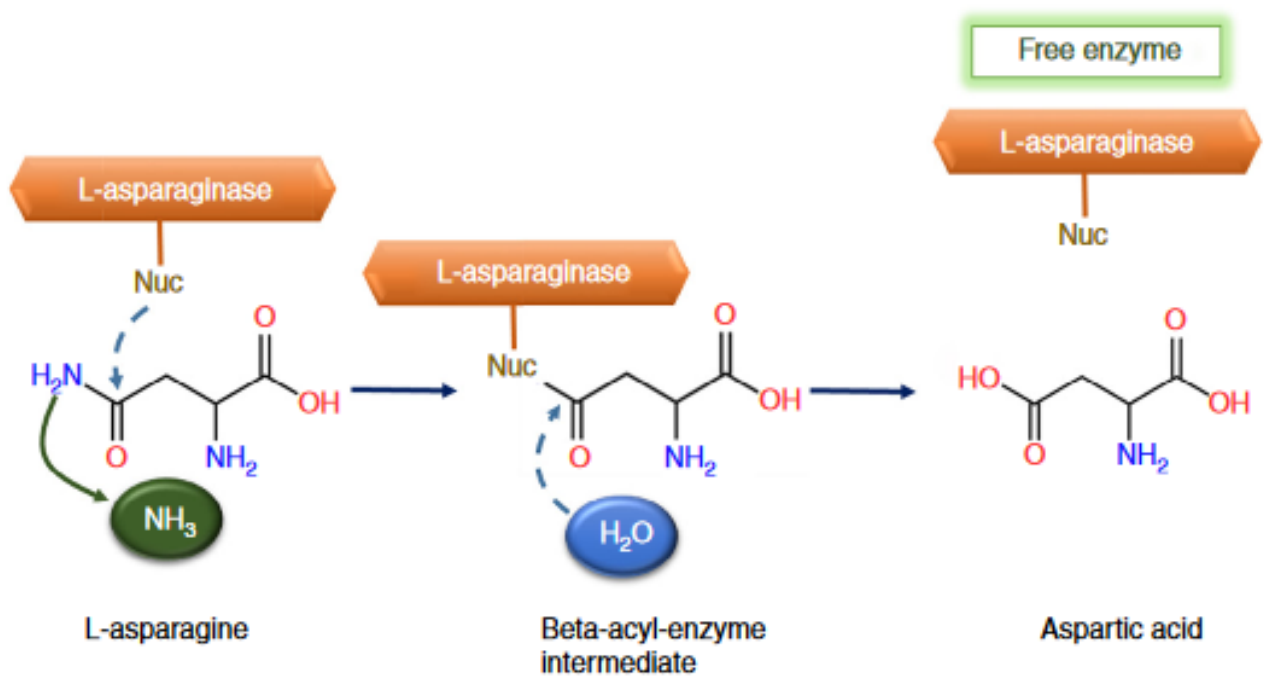

Fig. 1. The general mechanism of L-asparaginase catalyzed reactions [101].
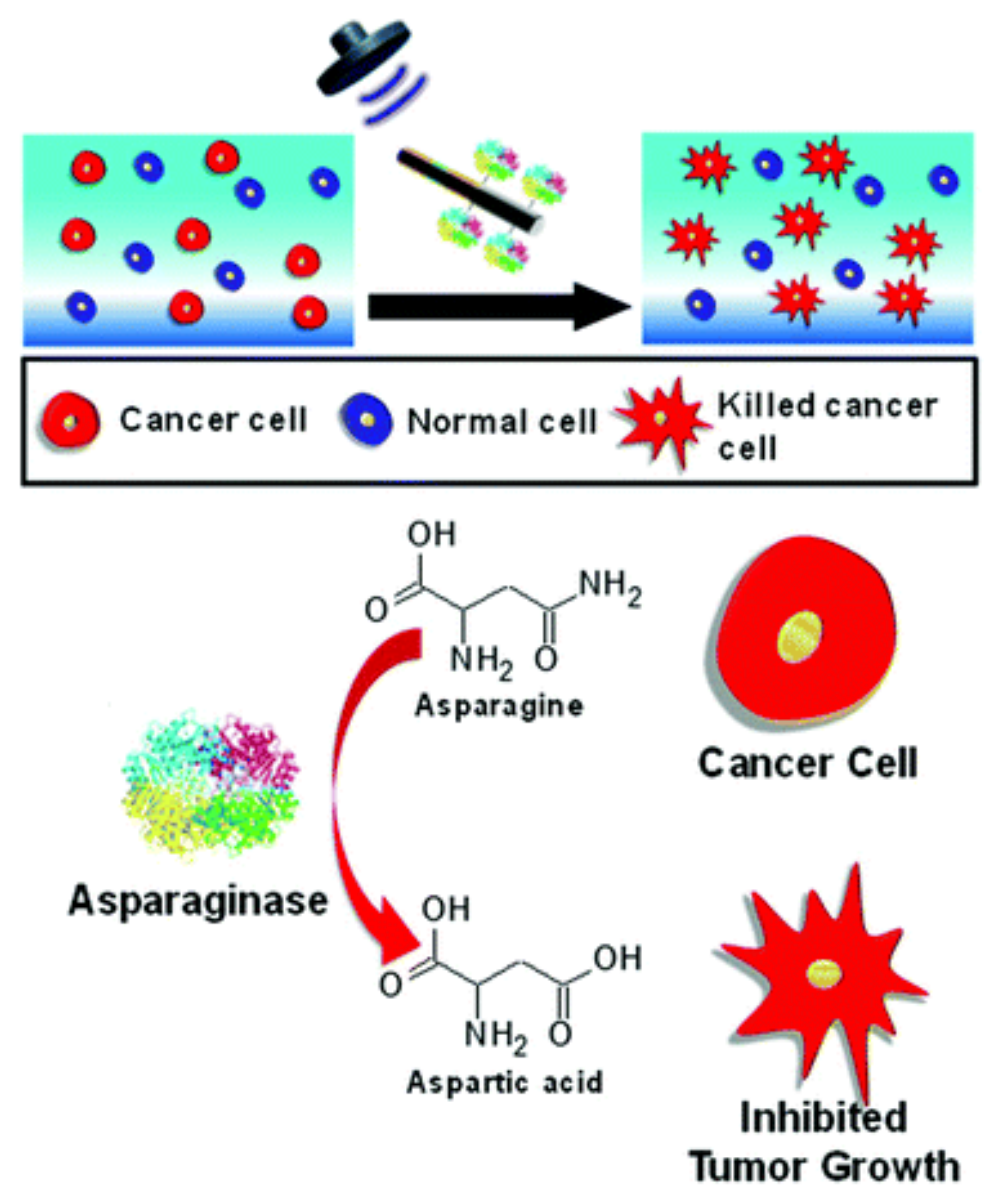

Fig. 2. Mechanism of action of L-asparaginase as an anticancer agent [102]. 


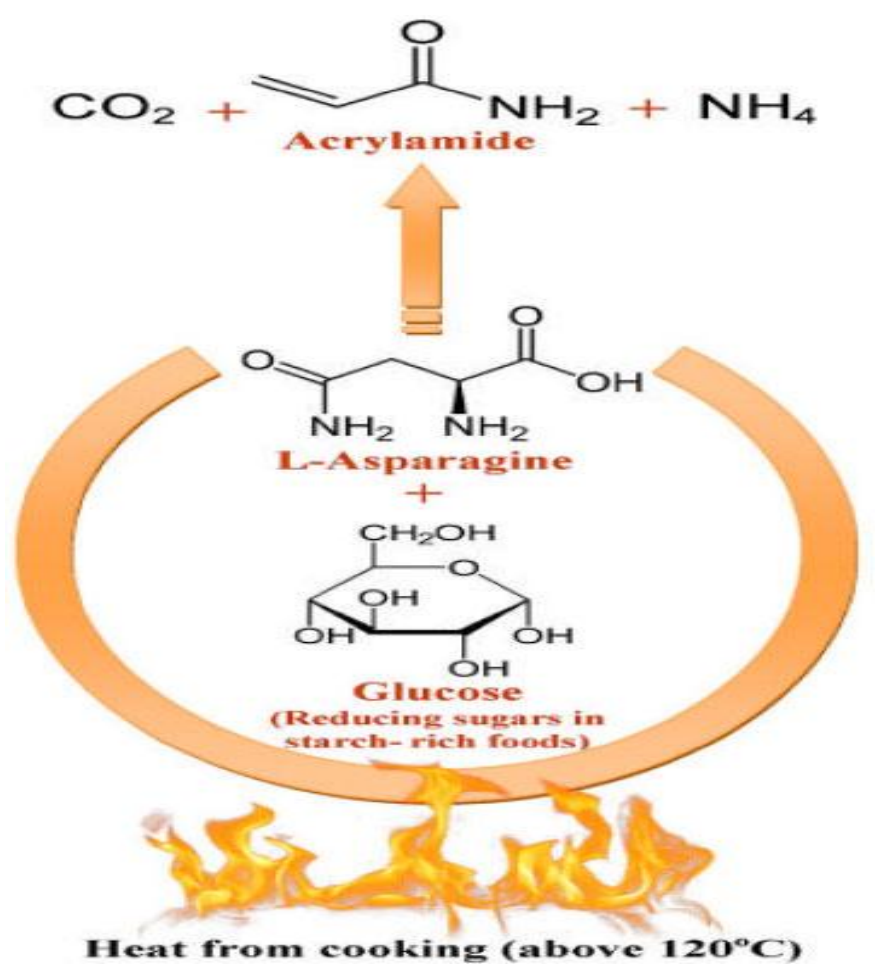

Fig. 3. Schematic illustration of acrylamide [8]

Fermentation techniques use certain microorganisms to devour the asparagine or reducing sugar prior to the step of food processing [21]. For example, a basal medium including lactic acid bacteria was utilized in the formation of wholemeal rye bread and considerably diminished levels of acrylamide in the final product [22]. In addition, of decreasing the $\mathrm{pH}$, the lactic acid bacteria lowered the amount of reducing sugars in the dough.

In the fermentation approach, there are many points which need to be taken into consideration. Starting with, the temperature and $\mathrm{pH}$ should be controlled in order to increase the activity of the microorganism to the maximum. Regardless of the reducing sugar consumed was included back after processing, the final product's quality may still be influenced by the fermentation step [23]. Besides, fermentation always works in bakery products, with restricted application in the products that are based on potato and also coffee [24].

The use of an enzymatic way to change the reaction pathways was first suggested by Amrein et al., who utilized asparaginase to break down the asparagine to aspartic acid and ammonia [25]. This technique is considered to be powerful because asparagine is not a high supporter of the flavor and color of cooked foods at all [26], so required sensory characteristics are kept up. Zyzak et al. mentioned that treatment of the potato product with L-asparaginase before cooking might help in $88 \%$ reduction of asparagine, as well as acrylamide decrease greater than $99 \%$ in the last cooked product [27]. Vass et al. deduced that at least $70 \%$ decrease in the acrylamide level of cracker products can be achieved by the addition of L-asparaginase during the preparation of the dough [28]. It is 
commercially available under the brand name Acrylaway $^{\circledR}$ and PreventASe ${ }^{\circledR}$ [7].

\subsection{L-asparaginase biosensor}

Biosensors to recognize asparagine have been made by the capture of L-asparaginase between $\mathrm{NH}_{3}$ gas permeable membrane and cellophane dialysis membrane [7], which finds deployment as a biosensor. Verma et al. performed researches on co-immobilization of L-asparaginase with phenol red indicator on the nitrocellulose membrane, silicone gel and calcium alginate beads, which can be utilized as a biosensor for diagnosis to detect asparagine in the blood samples of normal and leukemia patients by color visualization [29]. Verma et al. have developed an entire-cell based optic fiber biosensor using Lasparaginase-producing coliform bacteria and phenol red indicator immobilized with each other with Tetramethyl orthosilicate gel, which can discover approach in detecting L-asparagine content in food samples [30].

\subsection{Types of L-asparaginase}

Bacterial L-asparaginase has been categorized into two large groups named type I and type II based on the homology in the sequence, function, and structure, in addition to various asparaginases that are derived from plant origins [31]. Bacterial L-asparaginases belong to a group of amidohydrolases in which threonine is the essential nucleophile during catalysis. Type I Lasparaginases are cytoplasmic and type II are periplasmic, the latter have high affinity to Lasparagine $\left(\mathrm{Km}^{1 / 4} 10^{-5} \mathrm{M}\right)$, and to a lesser degree helps in the conversion of L-glutamine into glutamic acid. E.coli L-asparaginase type I and II have similar conserved amino acid motifs, but vary in their quaternary structure, and type I is with a much lower affinity towards L-asparagine $\left(\mathrm{Km}^{1 / 4} \quad 10^{-3} \mathrm{M}\right)$ [7]. Specific strains of yeasts produce L-asparaginases with the same amino acid sequences as the bacterial type II group [31].
The amino acid sequences of bacterial Lasparaginases have insignificant homology with plant L-asparaginases.

Plant asparaginases cannot break down glutamine. Most of the plants L-asparaginases are considered N-terminal nucleophile hydrolases that included in metabolic pathways associated with the assimilation of atmospheric nitrogen. Plant L-asparaginases have two types: potassiumdependent and potassium independent, both with prominent levels of sequence similarity to each other. The potassium-dependent enzyme is more broadly disseminated in higher plants and it can effectively metabolize L-asparagine during high metabolic need for nitrogen [32]. Yeast and bacterial L-asparaginases are considered type II L-asparaginase group. In spite of the fact that actinomycelial and fungal L-asparaginases are considered as microbial L-asparaginases, their alliance to the current types of L-asparaginases is not well defined [7].

\subsection{Sources of $L$-asparaginases}

L-asparaginase presents in different organisms, including animals, plants, and microorganisms (bacteria, fungi, algae, yeast, and actinomycetes) except humans. Even though Lasparaginase presents in various animal and plant groups, but because of its difficult extraction procedures, other conceivable sources (bacteria, fungi, algae, yeasts, and actinomycetes) were discovered by researchers [8]. Using the microbial systems for the production of $\mathrm{L}$ asparaginase has attracted the attention owing to its low cost and large quantity production by submerged and solid-state fermentation [33, 34].

\subsubsection{Bacterial sources}

L-asparaginase can be produced from both Gram-positive and Gram-negative bacterial species recovered from marine and terrestrial environment [35]. Regarding L-asparaginase, 
Gram-positive bacteria have attracted less attention when compared to Gram-negative [16]. The intensively studied species of both Gramnegative and Gram-positive classes, as Lasparaginase producers, are listed in table $\mathbf{1}$.

\subsubsection{Fungal source}

Along with the bacteria, there is another powerful source of L-asparaginase. Many side effects associated with bacterial asparaginase, which contradicts their application. This obstacle requires an approach for discovering a new source for L-asparaginase. In contrast to bacteria, fungi are more closely associated with humans. Therefore, fungal L-asparaginase will have less opportunity for immunological reaction [56]. In addition, fungal asparaginase has great importance, as it is an extracellular enzyme. Different L-asparaginase-producing fungi are being mentioned as follows: Alternaria sp. [57], Aspergillus nidulans [58], Aspergillus niger [59], Aspergillus oryzae [60], Aspergillus tamarii [61], Aspergillus terreus [62], Cylidrocapron

Table 1: Bacterial sources of L-asparaginase obtusisporum [63], Mucor sp.[64] and Fusarium roseum [65].

\subsubsection{Actinomycetes source}

Actinomycetes also produce L-asparaginase. Actinomycetes are broadly abundant in water and soil, but the ones that presented in living animals particularly in fishes are considered to possess high enzymatic activity. As well as, actinomycetes are found to be a good source of L-asparaginase when compared to fungi and bacteria [66]. L-asparaginase-producing actinomycetes as Actinomyces sp. [67], Streptomyces albidoflavus [68], Streptomyces aurantiacus [68], Streptomyces collinus [69], Streptomyces griseus [70], Streptomyces gulbargensis [71], Streptomyces karnatakensis [72], Streptomyces longsporusflavus [33], Streptomyces plicatus [73] and Streptomyces tendae [74].

\begin{tabular}{llll}
\hline Gram positive bacteria & References & Gram negative bacteria & References \\
\hline Bacillus circulans & {$[\mathbf{3 6}, \mathbf{3 7}]$} & Acinetobacter calcoaceticus & {$[\mathbf{3 8}]$} \\
Bacillus coagulans & {$[\mathbf{8}]$} & Azotobacter agilis & {$[\mathbf{8}]$} \\
Bacillus sp. & {$[\mathbf{3 9}]$} & Serratia marcescens & {$[\mathbf{4 0}]$} \\
Bacillus mesentericus & {$[\mathbf{8}]$} & Citrobacter sp. & {$[\mathbf{4 1}]$} \\
Bacillus polymyxa & {$[\mathbf{4 2}]$} & Escherichia coli & {$[\mathbf{4 3}]$} \\
Bacillus subtilis & {$[\mathbf{4 4}]$} & Enterobacter aerogenes & {$[\mathbf{4 5}]$} \\
Bacillus licheniformis & {$[\mathbf{4 6 , 4 7 ]}$} & Vibrio succinogenes & {$[\mathbf{8}]$} \\
Corynebacterium glutamicum & {$[\mathbf{4 8}]$} & Erwinia cartovora & {$[\mathbf{4 9}]$} \\
Mycobacterium bovis & {$[\mathbf{8}]$} & Erwinia chrysanthemi & {$[\mathbf{5 0}]$} \\
Staphylococcus sp. & {$[\mathbf{5 1}]$} & Helicobacter pylori & {$[\mathbf{5 2}]$} \\
Staphylococcus aureus & {$[\mathbf{5 3}]$} & Klebsiella pneumoniae & {$[\mathbf{5 4}]$} \\
Streptococcus albus & & & {$[\mathbf{5 5}]$} \\
\hline
\end{tabular}




\subsubsection{Plant source}

L-asparaginase is a good tumor inhibitor, so a number of new sources must be discovered in order to meet the need of the medical industry. Researchers have mentioned that green chilies (Capsicum annum) and tamarind (Tamarindus indica) can produce an amount of L-asparaginase. An enzyme produced from the green chilies was highly purified up to 400 -folds by various techniques and it was detected that enzyme appear in two forms, one of them are found to have a tumor inhibiting effect [9].

\subsection{L-asparaginase structure}

Many researchers to find out L-asparaginase molecular structure have performed many studies. After isolation of L-asparaginase from various sources, it was mentioned that Lasparaginase usually presents as a tetramer and may appear as monomeric, dimeric and hexameric forms. L-asparaginases from bacterial source mostly possess quaternary and tertiary structures [75]. E. coli and Erwinia sp. Lasparaginases are studied in a good way so their structures at the molecular levels and their information is easily abundant [76, 77]. Both $E$. coli and Erwinia sp. are identical in the threedimensional structures [78]. Erwinia carotovora L-asparaginase existed as two tetramers formed from four similar monomers each. I each monomer, three hundred twenty-seven amino acids gather with $14 \alpha$-strands, eight $\beta$-helices [79], and two domains, a big N-terminal domain and a small C-terminal domain [76]. In between the two adjoining monomers, the active site is located. The tetramer formed from four identical subunits. The entire molecule is observed as a dimer of dimers $[\mathbf{8 0}, \mathbf{8 1}]$.

\subsection{Immunological reaction}

By increasing the molecular weight of the protein, higher structure complexity and proteins made of many similar subunits with a molecular weight of $>100 \mathrm{KDa}$ the immunogenicity of the protein becomes higher. Clinical trials have demonstrated that the application of the asparaginase molecule, which comprises four similar subunits and has about $140 \mathrm{KDa}$ molecular weight leads to the production of certain antibodies in numerous patients. The antibody reactions range from systemic anaphylaxis to localized erythema and pain at the site of injection and may be followed by a high rate of inactivation to the enzyme. In some reports, the asparaginase is inactivated rapidly in patients who don't show hypersensitivity clinical signs which are called 'silent inactivation' [82]. Killander et al. tested L-asparaginase from $E$. coli in two sets including 57 children and 57 adults and revealed that in the adults there were the more frequent appearance of hypersensitivity reactions and a reduction in asparaginase activity in addition to specific antibodies than in the children [83]. As asparaginases from various bacterial strains are accessible which demonstrate only restricted cross-reactivity, regimen continuation in case of immunological reactions to one preparation of asparaginase may be conceivable by choosing an enzyme from a various biological source [12]. As overall, proteins are immunogenic when the molecular weight higher than $6 \mathrm{kDa}$ [7].

\subsection{Industrial production of $\mathbf{L}$-asparaginase and process optimization}

Many parameters need to be taken into consideration for the industrial production of Lasparaginase, intending to a higher production and cost-effective process. The $\mathrm{pH}$, temperature, type, and concentration of carbon and nitrogen sources, aeration, fermentation time, and, particularly, the biological agent, have an extraordinary impact on the process [84]. As mentioned before, many microorganisms are displayed as L-asparaginase producers; however, bacteria E. coli and Erwinia chrysanthemi are the 
present main microbial sources for industrial production in the pharmaceutical region, while the fungus Aspergillus oryzae is the most commonly used in the food industry $[\mathbf{6 0}, \mathbf{8 5}]$. Fig. 4 shows a schematic diagram of the industrial procedures for L-asparaginase production.

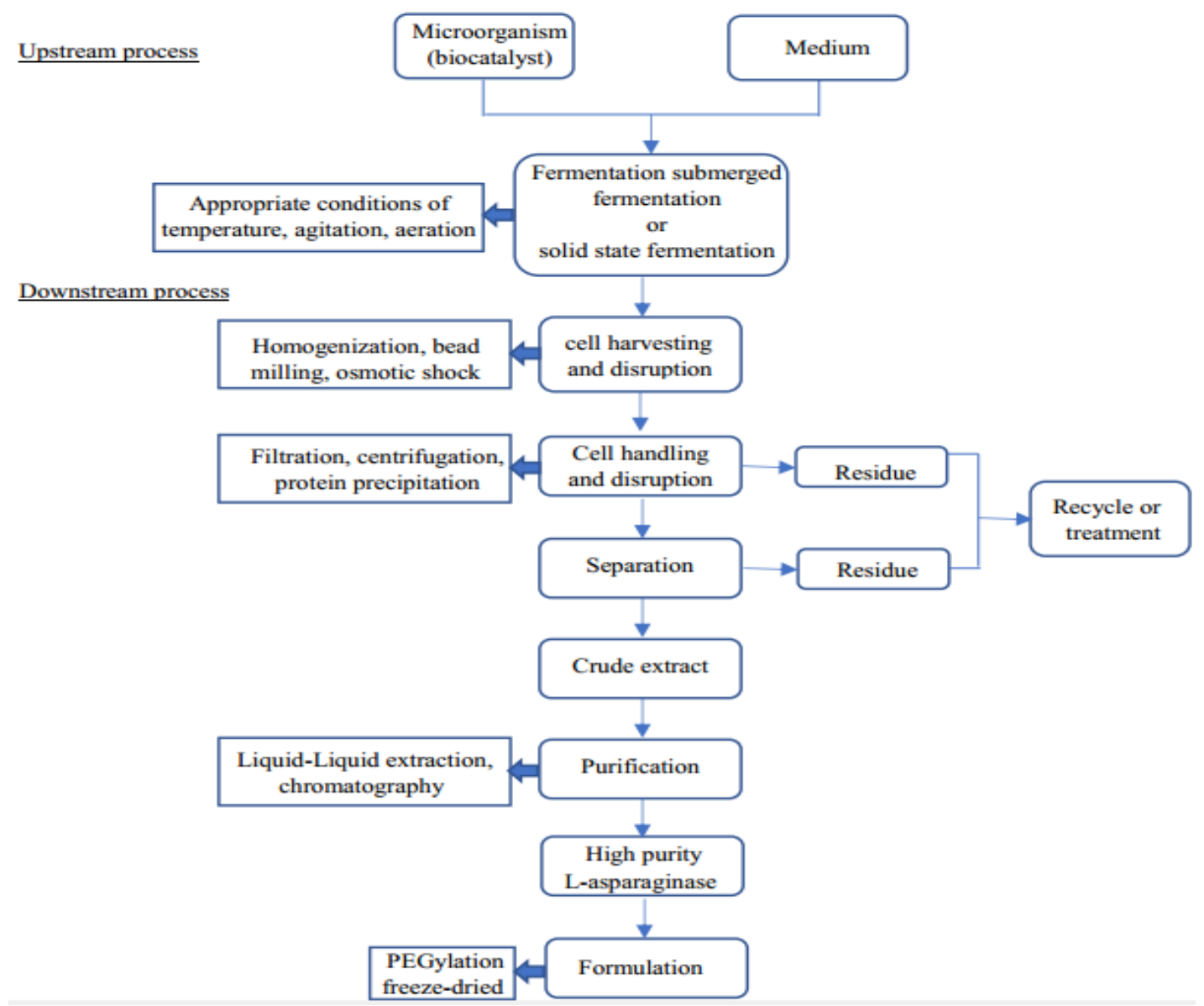

Fig. 4. Schematic representation for an industrial process for L-asparaginase production [101].

For L-asparaginase production, various types of culture media have been investigated. Nonetheless, carbon and nitrogen sources are the most affecting parts of the medium. For example, different investigations have presented that best nitrogen source for reaching high yields are Lasparagine, L-glutamine and L-proline [86-89] and glucose is found to be the most common carbon source, as well as other sources such as starch and maltose $[87,90,91]$. By studying the different concentration of glucose, it displayed catabolic repression on enzyme production.
Glucose at $1 \%$ totally represses the enzyme activity while at $0.1 \%$, it presented marginally stimulatory impact on enzyme production [4]. The production of L-asparaginase was observed by utilizing inorganic nitrogen sources such as ammonium sulfate, ammonium chloride, and ammonium nitrate as well as organic sources such as peptone, yeast extract, and beef extract. The optimum productivity has been reported by using $0.5 \%$ yeast extract and $0.5 \%$ ammonium sulfate. Consequently, yeast extract and ammonium sulfate have been considered as the 
best nitrogen sources [92]. As aeration and agitation were the influencing parameters for the enzyme production, low aeration and agitation gave the higher yield production while complete aerobic and anaerobic conditions lowered the yield.

Various techniques stated for production and optimization of L-asparaginase from different microorganisms incorporate solid-state fermentation (SSF) and submerged fermentation (SmF) [93]. Conditions of the process differ from organism to another for enzyme production, and it can be formed constitutively or after induction [94]. Production of L-asparaginase using submerged fermentation was performed by Moorthy et al. [95]. The culture conditions were optimized for the higher production of the enzyme. Two carbon sources, glucose and maltose, were utilized for the enzyme production. Glucose provided better outcomes. The enzyme was activated by $\mathrm{MgCl}_{2}$ and inhibited by EDTA. Nutritional demands for L-asparaginase production from Fusarium species was examined by Tippani and Sivadevuni [89], using submerged fermentation. Glucose was found to be the best carbon source with Fusarium semitectum (328 $\mathrm{IU} / \mathrm{mL})$, Fusarium moniliforme (300 IU/mL) and Fusarium oxysporum (210 IU/mL), while lactose was the second best carbon source for Fusarium oxysporum (178 IU/mL) and Fusarium semitectum (218 IU/mL) and for Fusarium moniliforme mannose was the best one (213 $\mathrm{IU} / \mathrm{mL}$ ) [4]. Nevertheless, solid state fermentation has some advantages including high yield, costeffective, low energy input, simple fermentation media, and low water utilization $[96,97]$.

Solid-state fermentation has been developed as an effective technology for the production of microorganisms' products using raw materials of low cost. An approach was performed by Hosamani et al., for optimization of Lasparaginase production by Fusarium equiseti utilizing the soya bean under solid state fermentation (SSF), soya bean provided one of the best L-asparaginase yields [92]. The production began at $24 \mathrm{~h}$ till maximum production at $48 \mathrm{~h}$ and then significantly decreased by increasing the incubation time [92]. For Erwinia carotovora, the optimization was performed using Response Surface Methodology (RSM) [Central Composite Rotatable Design (CCRD)] to test the influence of combination for the three variables. Yeast Extract, Maltose, and L-asparagine, which were, detected earlier using 'one-factor-at-a time' attempt by them. Within the three variables, yeast extract was found to be significant of maximum productivity 107.46 IU. [98]. M. Sunitha et al. utilized the PlackettBurman design to detect the media components controlling the enzyme productivity. They utilized the Bacillus cereus MNTG-7 as the source [99]. Streptomyces gulbargensis was improved by mutagenesis, which enabled isolation of strains that could produce a high yield of the enzyme. The mutant revealed the maximum L-asparaginase productivity (44.7 IU) at $120 \mathrm{~h}$ of fermentation via utilizing ground cake extract medium. Abdel-Fattah et al. have studied L-asparaginase production by Pseudomonas aeruginosa in solid-state culture. Reaction conditions were optimized using PlackettBurman design [33]. The most significant factors were $\mathrm{pH}$, casein hydrolysate and corn-steep liquor and their optimal values as stated by Box-

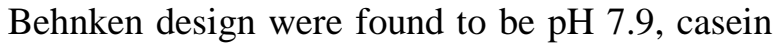
hydrolysate $3.11 \%$, and corn-steep liquor $3.6 \%$ [100].

\section{Conclusion}

This review article highlights miscellaneous applications of L-asparaginase on the commercial level including medical or food industries as well as improvements of its production processes. Several reports have emphasized on the promising role of L-asparaginase in cancer 
therapy. Furthermore, L-asparaginase has been introduced in the food industry for the elimination of the carcinogenic compound (acrylamide). In spite of its availability from different sources, microbial L-asparaginase has attracted the attention of the scientists due to its cost-effectiveness and ease of the production. Owing to its commercial value, different approaches have been implemented to optimize L-asparaginase production for higher microbial yields on the industrial level.

\section{Conflict of Interest}

The authors declare no conflict of interest.

\section{References}

1. Nigam PS. Microbial enzymes with special characteristics for biotechnological applications. Biomolecules. 2013; 3(3):597611.

2. Periasamy Anbu, Subash CB Gopinath, Arzu Coleri Cihan, Bidur Prasad Chaulagain. Microbial enzymes and their applications in industries and medicine. Biomed Res int. 2013; 2013:1-13.

3. Anbu P, S.C.B. Gopinath, A.C. Cihan, B.P. Chaulagain. Strategies to characterize fungal lipases for applications in medicine and dairy industry. Biomed Res int. 2013:1-2.

4. Sinha R, Singh HR, Jha SK. Microbial Lasparaginase: present and future prospective. Int J Innov Res Sci Eng. 2013; 2(11):7031-51.

5. Bansal S, Srivastava A, Mukherjee G, Pandey R, Verma AK, Mishra P, et al. Hyperthermophilic asparaginase mutants with enhanced substrate affinity and antineoplastic activity: structural insights on their mechanism of action. FASEB J. 2012; 26(3):1161-71.

6. Piatkowska-Jakubas B, Krawczyk-Kuliś M, Giebel S, Adamczyk-Cioch M, Czyz A, Lech $\mathrm{ME}$, et al. Use of L-asparaginase in acute lymphoblastic leukemia: recommendations of the Polish Adult Leukemia Group. Pol Arch Med Wewn. 2008;118(11):664-9.

7. Krishnapura PR, Belur PD, Subramanya S. A critical review on properties and applications of microbial 1-asparaginases. Crit Revi Microbiol. 2016;42(5):720-37.

8. Batool T, Makky EA, Muna Jalal, Mashitah M Yusoff. A comprehensive review of Lasparaginase and its applications. Appl Biochem Biotechnol. 2016; 178(5):900-23.

9. Kumar J, S, Pasrija D, Sinha RK, Singh HR, Nigam VK, Vidyarthi AS. Microbial Lasparaginase: a review on current scenario and future prospects. Int J Pharm Sci and Res. 2012; 3(9):3076-90.

10. Souza PM, de Freitas MM, Cardoso SL, Pessoa A, Guerra ENS, Magalhães PO. Optimization and purification of 1-asparaginase from fungi: A systematic review. Crit Rev Oncol Hematol. 2017;120:194-202.

11. Prager MD, Bachynsky N. Asparagine synthetase in asparaginase resistant and susceptible mouse lymphomas. Biochem Biophys Res Comm. 1968; 31(1):43-7.

12. Boos J. Use of 1-asparaginase in childhood ALL. Crit Rev Oncol Hematol. 1998; 2(28):97-113.

13. Ohnuma T, Bergel F, Bray R. Enzymes in cancer: asparaginase from chicken liver. Biochem J. 1967; 103(1):238.

14. Richards NG, Kilberg MS. Asparagine synthetase chemotherapy. Annu Rev Biochem. 2006; 75:629-54.

15. Ueno T, Ohtawa K, Mitsui K, Kodera Y, Hiroto M, Matsushima A. Cell cycle arrest and apoptosis of leukemia cells induced by Lasparaginase. Leukemia. 1997; 11(11):1858.

16. Asthana N, Azmi W. Microbial L-asparaginase: A potent antitumor enzyme. ind $\mathrm{J}$ Biotechnol. 2003;2:184-94. 
17. Mottram DS, Wedzicha BL, Dodson AT. Food chemistry: acrylamide is formed in the Maillard reaction. Nature. 2002; 419(6906):448.

18. Pedreschi F, Mariotti MS, Granby K. Current issues in dietary acrylamide: formation, mitigation, and risk assessment. J Sci Food Agric. 2014;94(1):9-20.

19. Yu LL, Wang S, Sun B-G. Food safety chemistry: toxicant occurrence, analysis, and mitigation: CRC press; 2014.

20. Xu F, Oruna-Concha M-J, Elmore JS. The use of asparaginase to reduce acrylamide levels in cooked food. Food Chem. 2016; 210:163-71.

21. Sadd PA, Hamlet CG, Liang L. Effectiveness of methods for reducing acrylamide in bakery products. J agric food chem. 2008; 56(15):6154-61.

22. Bartkiene E, Jakobsone I, Juodeikiene G, Vidmantiene D, Pugajeva I, Bartkevics V. Study on the reduction of acrylamide in mixed rye bread by fermentation with bacteriocin-like inhibitory substances producing lactic acid bacteria in combination with Aspergillus niger glucoamylase. Food Control. 2013; 30(1):3540 .

23. Bartkiene E, Jakobsone I, Juodeikiene G, Vidmantiene D, Pugajeva I, Bartkevics V. Effect of lactic acid fermentation of lupine wholemeal on acrylamide content and quality characteristics of wheat-lupine bread. Int $\mathrm{j}$ food sci nutr. 2013; 64(7):890-6.

24. Kamkar A, Qajarbeygi P, Jannat B, Haj Hosseini Babaei A, Misaghi A, Molaee Aghaee E. The inhibitory role of autolyzed yeast of Saccharomyces cerevisiae, vitamins B3 and B6 on acrylamide formation in potato chips. Toxin Rev. 2015; 34(1):1-5.

25. Boegl p, Zuzana C, Eugen K. Impact of Lasparaginase on acrylamide content in potato products. J Food Nutr Res. 2006;45(4):141-6.

26. Parker JK, Balagiannis DP, Higley J, Smith G, Wedzicha BL, Mottram DS. Kinetic model for the formation of acrylamide during the finishfrying of commercial French fries. J Agr Food Chem. 2012;60(36):9321-31.

27. Zyzak DV, Sanders RA, Stojanovic M, Tallmadge DH, Eberhart BL, Ewald DK, et al. Acrylamide formation mechanism in heated foods. J Agr Food Chem. 2003; 51(16):4782-7.

28. Vass M, Amrein T, Schonbachler B, Escher F, Amado R. Ways to reduce the acrylamide formation in cracker products. Czech J Food Sci. 2004;22(I): 19 .

29. Verma N, Kumar K, Kaur G, Anand S. E. coli K-12 asparaginase-based asparagine biosensor for leukemia. Artif Cells Blood Substit Biotechnol. 2007; 35(4):449-56.

30. Verma N, Bansal M, Kumar S. Whole cell based miniaturized fiber optic biosensor to monitor L-asparagine. Adv Appl Sci Res. 2012; 3(2):809-14.

31. Borek D, Jaskólski M. Sequence analysis of enzymes with asparaginase activity. Acta Biochim Pol. 2001; 48:893-902.

32. Bruneau L, Chapman R, Marsolais F. Cooccurrence of both L-asparaginase subtypes in Arabidopsis: At3g16150 encodes a K+dependent L-asparaginase. Planta. 2006; 224(3):668-79.

33. Abdel-Fattah YR, Olama ZA. L-asparaginase production by Pseudomonas aeruginosa in solid-state culture: evaluation and optimization of culture conditions using factorial designs. Process Biochem. 2002; 38(1):115-22.

34. Kumar S, Dasu VV, Pakshirajan K. Purification and characterization of glutaminase-free Lasparaginase from Pectobacterium carotovorum MTCC 1428. Bioresour Technol. 2011; 102(2):2077-82.

35. Izadpanah QF, Javadpour S, Malekzadeh K, Tamadoni Jahromi S, Rahimzadeh M. Persian gulf is a bioresource of potent L-asparaginase producing bacteria: Isolation \& molecular differentiating. Int J Environ Res. 2014; 8(3):813-8. 
36. Hymavathi M, Sathish T, Rao CS, Prakasham R. Enhancement of L-asparaginase production by isolated Bacillus circulans (MTCC 8574) using response surface methodology. Appl Biochem Biotechnol. 2009; 159(1):191-8.

37. Prakasham R, Hymavathi M, Rao CS, Arepalli S, Rao JV, Kennady PK, et al. Evaluation of antineoplastic activity of extracellular asparaginase produced by isolated Bacillus circulans. Appl Biochem Biotechnol. 2010; 160(1):72.

38. Joner PE. Purification and properties of $1-$ asparaginase B from Acinetobacter calcoaceticus. Biochimica et Biophysica Acta (BBA)-Enzymology. 1976;438(1):287-95.

39. Mohapatra B, Sani R, Banerjee U. Characterization of L-asparaginase from Bacillus sp. isolated from an intertidal marine alga (Sargassum sp.). Lett Appl Microbiol. 1995; 21(6):380 3.

40. Rowly B, Wriston J. L-asparaginase from Serratia marcescens. Biochem Biophys Res Commun. 1967; 28:160-71.

41. Shoshana B, Banks G, Skarstedt M, Fleming A, Bettelheim K, Connors T. The properties and large-scale production of L-asparaginase from Citrobacter. Microbiology. 1975; 91(1):1-16.

42. Nefelova M, Ignatov S, Chigalenchik A, Vinogradov B, Egorov N. Biosynthesis of Lasparaginase-2 by cultures of Bacillus polymyxa var. Ross. Prikladnaia biokhimiia i mikrobiologiia. 1978; 14(4):510-4.

43. Netrval J. Stimulation of L-asparaginase production in Escherichia coli by organic and amino acids. Folia microbiol. 1977;22(2):10616.

44. Fisher SH, Wray LV. Bacillus subtilis 168 contains two differentially regulated genes encoding L-asparaginase. J Bacteriol. 2002; 184(8):2148-54.

45. Mukherjee J, Majumdar S, Scheper T. Studies on nutritional and oxygen requirements for production of L-asparaginase by Enterobacter aerogenes. Appl Microbiol Biotechnol. 2000; 53(2):180-4.

46. Golden KJ, Bernlohr RW. Nitrogen catabolite repression of the L-asparaginase of Bacillus licheniformis. J Bacteriol. 1985; 164(2):93840.

47. Sudhir AP, Dave BR, Prajapati AS, Panchal K, Patel D, Subramanian R. Characterization of a recombinant glutaminase-free 1-asparaginase (ansa3) enzyme with high catalytic activity from Bacillus licheniformis. Appl Biochem Biotechnol. 2014; 174(7):2504-15.

48. Mesas JM, Gil JA, Martín JF. Characterization and partial purification of $\mathrm{L}$-asparaginase from Corynebacterium glutamicum. Microbiology. 1990; 136(3):515-9.

49. Maladkar N, Singh V, Naik S. Fermentative production and isolation of L-asparaginase from Erwinia carotovora, EC-113. Hindustan Antibiot bull. 1993; 35(1-2):77-86.

50. Moola ZB, Scawen M, Atkinson T, Nicholls D. Erwinia chrysanthemi L-asparaginase: epitope mapping and production of antigenically modified enzymes. Biochem J. 1994; 302(3):921-7.

51. Mikucki J, Szarapińska-Kwaszewska J, Krzemiński Z. Factors influencing Lasparaginase production by Staphylococci. Zentralbl Bakteriol Parasitenkd Infektionskr Hyg. 1977; 132(2):135-42.

52. Stark R, Suleiman M-S, Hassan I, Greenman J, Millar M. Amino acid utilisation and deamination of glutamine and asparagine by Helicobacter pylori. J Med Microbiol. 1997;46(9):793-800.

53. Rozalska M, Mikucki J. Staphylococcal Lasparaginase: catabolic repression of synthesis. Acta Microbiologica Polonica. 1992; 41(34):145-50.

54. Reddy K. Effect of $\mathrm{C}$ and $\mathrm{N}$ sources on asparaginase production by bacteria. Ind $\mathrm{J}$ Microbiol 1990;30(1):81-3. 
55. Zhang N, Clarke F, Di Trapani G, Keough D, Beacham I. Guinea pig serum L-asparaginase: purification, and immunological relationship to liver L-asparaginase and serum Lasparaginases in other mammals. Comp Biochem Physiol B, Biochem Mol Biol. 1995; 112(4):607-12.

56. Shrivastava A, Khan AA, Shrivastav A, Jain SK, Singhal PK. Kinetic studies of Lasparaginase from Penicillium digitatum. Prep Biochem Biotechnol. 2012; 42(6):574-81.

57. Gummadi C. Screening and isolation of novel glutaminase free L-asparaginase from fungal endophytes. Res J Microbiol. 2014; 9(4):16376.

58. Saxena RK, Sinha U. L-asparaginase and glutaminase activities in the culture filtrates of Aspergillus nidulans. Curr sci. 1981; 50:218-9.

59. Mishra A. Production of L-asparaginase, an anticancer agent, from Aspergillus niger using agricultural waste in solid state fermentation. Appl Biochem Biotechnol. 2006; 135(1):3342.

60. Hendriksen HV, Kornbrust BA, Østergaard PR, Stringer MA. Evaluating the potential for enzymatic acrylamide mitigation in a range of food products using an asparaginase from Aspergillus oryzae. J Agr Food Chem. 2009; 57(10):4168-76.

61. Sarquis MIdM, Oliveira EMM, Santos AS, Costa GLd. Production of L-asparaginase by filamentous fungi. Mem Inst Oswaldo Cruz. 2004; 99(5):489-92.

62. Gurunathan B, Sahadevan R. Production of Lasparaginase from natural substrates by Aspergillus terreus MTCC 1782: Effect of substrate, supplementary nitrogen source and L-asparagine. Int $\mathrm{J}$ Chem React Eng. 2009;7(1):doi.org/10.2202/1542-6580.2050.

63. Raha S, Roy S, Dey S, Chakrabarty S. Purification and properties of an Lasparaginase from Cylindrocarpon obtusisporum MB-10. Biochem Int. 1990; 21(6):987-1000.
64. Mohapatra B, Bapuji M, Banerjee U. Production and properties of L-asparaginase from Mucor species associated with a marine sponge (Spirastrella sp.). Cytobios. 1997; 92(370371):165-73.

65. Nakahama K, Imada A, Igarasi S, Tubaki K. Formation of L-asparaginase by Fusarium species. Microbiology. 1973;75(2):269-73.

66. Sahu MK, Sivakumar K, Poorani E, Thangaradjou T, Kannan L. Studies on Lasparaginase enzyme of actinomycetes isolated from estuarine fishes. J Environ Biol. 2007; 28(2):465.

67. Narayana K, Kumar K, Vijayalakshmi M. Lasparaginase production by Streptomyces albidoflavus. Ind J Microbiol. 2008; 48(3):331-6.

68.Gupta N, Mishra S, Basak U. Occurrence of Streptomyces aurantiacus in mangroves of Bhitarkanika. Malays J Microbiol. 2007;3(2):7-14.

69. Mostafa S, Salama M. L-asparaginaseproducing Streptomyces from the soil of Kuwait. Zentralbl Bakteriol Naturwiss. 1979; 134(4):325-34.

70. Dejong PJ. L-Asparaginase production by Streptomyces griseus. Appl Microbiol. 1972; 23(6):1163-4.

71. Amena S, Vishalakshi N, Prabhakar M, Dayanand A, Lingappa K. Production, purification and characterization of Lasparaginase from Streptomyces gulbargensis. Braz J Microbiol. 2010; 41(1):173-8.

72. Mostafa S. Activity of L-asparaginase in cells of Streptomyces karnatakensis. Zentralbl Bakteriol Naturwiss. 1979; 134(4):343-51.

73. Koshy A, Dhevendaran K, Georgekutty M, Natarajan P. L-asparaginase in Streptomyces plicatus isolated from the alimentary canal of the fish, Gerres filamentosus (Cuvier). J Mar Biotechnol. 1997; 5:181-5. 
74. Kavitha A, Vijayalakshmi M. Optimization and Purifi cation of L-Asparaginase Produced by Streptomyces tendae TK-VL_333. Z Naturforsch C. 2010; 65(7-8):528-31.

75. Ramya L, Doble M, Rekha V, Pulicherla K. LAsparaginase as potent anti-leukemic agent and its significance of having reduced glutaminase side activity for better treatment of acute lymphoblastic leukemia. Appl Biochem Biotechnol. 2012;167(8):2144-59.

76. Aghaiypour K, Wlodawer A, Lubkowski J. Structural basis for the activity and substrate specificity of Erwinia chrysanthemi Lasparaginase. Biochemistry. 2001; 40(19):5655-64.

77. Swain AL, Jaskólski M, Housset D, Rao J, Wlodawer A. Crystal structure of Escherichia coli $\mathrm{L}$-asparaginase, an enzyme used in cancer therapy. Proc Nat Acad Sci. 1993; 90(4):14748.

78. Lubkowski J, Dauter M, Aghaiypour K, Wlodawer A, Dauter Z. Atomic resolution structure of Erwinia chrysanthemi Lasparaginase. Acta Cryst D. 2003; 59(1):84-92.

79. Kozak M, Jaskólski M, Rohm K. Preliminary crystallographic studies of $\mathrm{Y} 25 \mathrm{~F}$ mutant of periplasmic Escherichia coli L-asparaginase. Acta Biochim Pol. 2000;47(3):807-14.

80. Jaskolski M, Kozak M, Lubkowski J, Palm G, Wlodawer A. Structures of two highly homologous bacterial 1-asparaginases: a case of enantiomorphic space groups. Acta Cryst D. 2001; 57(3):369-77.

81. Sanches M, Barbosa JaAR, De Oliveira RT, Abrahão Neto J, Polikarpov I. Structural comparison of Escherichia coli L-asparaginase in two monoclinic space groups. Acta Cryst D. 2003; 59(3):416-22.

82. Ahlke E, Nowak-Go“ Ttl U, Schulze-Westhoff P, Werber G, Bo" Rste H, WU“" Rthwein G, et al. Dose reduction of asparaginase under pharmacokinetic and pharmacodynamic control during induction therapy in children with acute lymphoblastic leukemia. Brit $\mathrm{J}$ Haematol. 1997; 96(4):675-81.

83. Killander D, Dohlwitz A, Engstedt L, Franzen S, Gahrton G, Gullbring B, et al. Hypersensitive reactions and antibody formation during L-asparaginase treatment of children and adults with acute leukemia. Cancer. 1976; 37(1):220-8.

84. Gurunathan B, Sahadevan R. Optimization of culture conditions and bench-scale production of L-asparaginase by submerged fermentation of Aspergillus terreus MTCC 1782. J Microbiol Biotechnol. 2012;22(7):923-9.

85. Lopes AM, Oliveira-Nascimento Ld, Ribeiro A, Tairum Jr CA, Breyer CA, Oliveira MAd, et al. Therapeutic l-asparaginase: upstream, downstream and beyond. Crit Rev Biotechnol. 2017; 37(1):82-99.

86. Baskar G, Renganathan S. Evaluation and screening of nitrogen source for 1-asparaginase production by Aspergillus terreus MTCC 1782 using latin square design. Res $\mathbf{J}$ Math Stat. 2009; 1(2):55-8.

87. Aida M, Farag, Sahar W, Hassan, Ehab A, Beltagy, Mohamed A, El-Shenawy. Optimization of production of anti-tumor 1asparaginase by free and immobilized marine Aspergillus terreus. Egypt J Aquat Res. 2015; 41(4):295-302.

88. Kiranmayi MU, Poda S, Vijayalakshmi M. Production and optimization of L-asparaginase by an actinobacterium isolated from Nizampatnam mangrove ecosystem. J Environ Biol. 2014;35(5):799.

89. Tippani R, Sivadevuni G. Nutritional factors effecting the production of L-asparaginase by the Fusarium sp. Afr J Biotechnol. 2012; 11(15):3692-6.

90. Vijayalakshmi M, Kavitha K, Akilandeswari K. Production of bioactive enzyme Lasparaginase from fungal isolates of water sample through submerged fermentation. Int JPharm Pharm Sci. 2012; 4(4):363-6. 
91. Varalakshmi V, Raju JK. Optimization of 1asparaginase production by Aspergillus terreus mtcc 1782 using bajra seed flour under solid state fermentation. Int $\mathbf{J}$ Res Eng Technol. 2013; 2(09):121-9.

92. Hosamani R, Kaliwal B. L-asparaginase an antitumor agent production by Fusarium equiseti using solid state fermentation. Int $\mathbf{J}$ Drug Discov. 2011;3(2):88-99.

93. Nagarethinam S, Naik AN, Udupa N, Rao VJ, Vanathi MB. Microbial L-Asparaginase and its future prospects. Asian J MedRes. 2012; 1(4):159-68.

94. Ahmad N, Pandit NP, Maheshwari SK. Lasparaginase gene-a therapeutic approach towards drugs for cancer cell. Int $\mathrm{J}$ Biosci. 2012; 2(4):1-11.

95. Moorthy V, Ramalingam A, Sumantha A, Shankaranaya RT. Production, purification, and characterization of extracellular Lasparaginase from a soil isolate of Bacillus sp. Afr J Microbiol Res. 2010; 4(18):1862-7.

96. Mishra A, Das MD. Effect of $\mathrm{pH}$ on simultaneous saccharification and isomerization by glucoamylase and glucose isomerase. Appl Biochem Biotechnol. 2002; 102(1-6):193-9.

97. Mukherjee P, Pandey A, Selvakumar P, Ashakumary L, Gurusamy P. X-ray diffraction studies on solid state fermentation for the production of glucoamylase using Aspergillus niger NCIM 1248. J Sci Ind Res. 1998; 57(1011):583-6.

98. Deokar VD, Vetal MD, Lambert Rodrigues. Production of intracellular L-asparaginase from Erwinia carotovora and its statistical optimization using response surface methodology (RSM). Int J Chem Sci. 2010; 1:25-36.

99. Sunitha M, Ellaiah P, Devi RB. Screening and optimization of nutrients for L-asparaginase production by Bacillus cereus MNTG-7 in SmF by plackett-burmann design. Afr JMicrobiol Res. 2010; 4(4):297-303.
100. El-Bessoumy AA, Sarhan M, Mansour J. Production, isolation, and purification of $\mathrm{L}$ asparaginase from Pseudomonas aeruginosa 50071 using solid-state fermentation. BMB Reports. 2004; 37(4):387-93.

101. Cachumba JJM, Antunes FAF, Peres GFD, Brumano LP, Dos Santos JC, Da Silva SS. Current applications and different approaches for microbial l-asparaginase production. Braz $\mathbf{J}$ Microbiol. 2016;47:77-85.

102. Uygun M, Jurado-Sánchez B, Uygun DA, Singh VV, Zhang L, Wang J. Ultrasoundpropelled nanowire motors enhance asparaginase enzymatic activity against cancer cells. Nanoscale. 2017; 9(46):18423-9. 